\title{
An Arcadian Poet in a Baroque City: Cláudio Manuel da Costa's Urban Pastorals, Family Life, and the Appearance of Race
}

\section{Bruno Carvalho}

Princeton University

\begin{abstract}
With focus on Cláudio Manuel da Costa and his life in eighteenth-century Minas Gerais, this article places into dialogue seemingly contradictory notions of baroque urbanism, art, and poetics. It explores how Cláudio's work engages baroque and Arcadian tropes, re-writing pastoral conventions with awareness of the production of nature through artifice. Some of his poems emerge as narratives of wilderness subsumed by colonial forces, others offer clues about his relationship with Francisca Arcângela de Souza, a woman of African descent (archival findings about her are presented here for the first time). Cláudio Manuel da Costa, a writer and public figure of many masks, helps us to make sense of tensions, changes, and apparent paradoxes of the period.
\end{abstract}

Keywords: Cláudio Manuel da Costa, Ouro Preto, Arcadismo, baroque, race.

A term that often evokes exuberance, fluidity, and excess, the baroque has itself been a dynamic, malleable, unstable concept. Its different meanings multiply across different contexts. Eighteenth-century Ouro Preto, the city of this essay's title, emerged during the twentieth century as a type of "cidade-síntese," "cidade-documento" of the Brazilian baroque (Ávila, Iniciação 27). To the poet, lawyer and businessman of this essay's title, the term would likely not have meant much. Widely regarded as one of the finest sonneteers of the Portuguese language and as a leading participant in the Inconfidência Mineira, Cláudio Manuel da Costa (1729-1789) lived in Ouro Preto when it was still known as 
Vila Rica, before discussions over the baroque took place, and when the city stood as the fulcrum of the mining economy of Minas Gerais. ${ }^{1}$

Any scholar of urbanism not versed in Brazilian cultural history or art would have trouble understanding Ouro Preto as a baroque city based on cartographic representations. At first glance, its streets do not conform to the typologies associated with baroque urbanity. To Lewis Mumford, who devoted a significant portion of his The City in History to the topic, the baroque approach privileged order, control, geometrical layouts, prodigality of space, and "its most imposing contribution, the long, straight, wide avenue [that] served ... to connect distant points quickly" (401). In Katherine Rinne's recent book on Rome's seventeenth-century water systems of fountains, aqueducts, drains and sewers - in what the subtitle deems "the birth of the baroque city" - she argues that Pius V's architectural patronage, "in large part due to the fact that he was obsessed with instituting the reforms of the Council of Trent far beyond the body of the Church and its members out into the city of Rome itself ..., laid the foundation for the order and the extravagances of the baroque city" (7).

Ángel Rama, in his seminal The Lettered City, identified similar patterns in Latin America, where colonizers saw the continent as an experimental field for imperial dreams of regularity and order: "The first methodical application of Baroque ideas was carried out by absolute monarchies in their New World empires, applying rigid principles-abstraction, rationalization, and systematization-and opposing all local expressions of particularity, imagination, or invention" (10). Although this interpretation certainly resonates with practices of the Portuguese Crown, it begs the question of how Brazilian baroque art entered cultural history for precisely such particularities, imagination and invention. And while Rama's description immediately evokes the grids of Spanish American colonial urban settlements, Ouro Preto appears to diverge from Lima or Mexico City even more than from Rome after its seventeenth-century reforms: one can scarcely find a right-angle or straight line among Ouro Preto's irregular, sinuous streets.

This morphological contrast inspired Sérgio Buarque de Holanda’s well known metaphor of the "semeador" and the "ladrilhador," differentiating the "desleixo" of Portuguese colonial city planning from the more systematic and 
ordered Spanish model (Raízes 95-149). Recent works approximate Spanish and Portuguese aims, adding nuance to the comparison. ${ }^{2}$ But the vision-and version - of the baroque awakened by Ouro Preto seem to be much more attuned to critical and theoretical traditions that seldom intersect with discourses of urban historians. We may think of Christine Buci-Glucksmann's invocation of a baroque town: "imagine a city with several entrances, a labyrinthine proliferation of squares, crossroads, thoroughfares and side streets, a kind of multibody of the past and memory" (39). The image conjures the Ouro Preto of a baroque aesthetic marked by rending, asymmetry and expressiveness, often with Aleijadinho as its avatar. ${ }^{3}$

How do we reconcile these diametrically opposing views of what constitutes a baroque city? The first impulse might be to resort to the familiar interpretations of the New World baroque as subverting the rigidity of Old World forms. Lois Parkinson Zamora and Monika Kaup, in the introduction to Baroque New Worlds, claim that "in all of the areas colonized by Catholic Europe, the Baroque was itself eventually colonized" by the cultural perspectives and techniques of "indigenous and African laborers and artisans" (3). While this view certainly provides an appropriate key through which to make sense of artistic and even architectonic innovations, it falls short of explaining broader patterns of urban design and development in Ouro Preto. Antonio Risério notes that the city's houses tended to be built in a familiar Portuguese style, whereas its religious architecture introduced changes (117). Echoing other scholars, he attributes this originality to the absence in Minas Gerais of regular religious orders, which freed up locals in ways that were usually not possible in colonial settings (118).

The socio-historical conditions in which new architectonic configurations germinated and flourished in Minas Gerais have been mapped out by a rich critical fortune. ${ }^{4}$ More recent reflections can also help us partly resolve the apparent contradictions between the irregularity of Ouro Preto's street layouts and Old World baroque urban order. Rodrigo Baeta, in "Ouro Preto: Cidade Barroca," argues against a search for typological or morphological elements in the task of comprehending baroque urban spaces. Rather, he seeks to direct our attention to an element of the baroque that seems to cut across its multiple 
and contradictory definitions: the primacy of the visual. ${ }^{5}$ Baeta dialogues with critics like Giulio Carlo Argan, who writes that the baroque principle's "intention ... was not to restore the absolute and universal value of form, but to affirm openly the autonomous and intrinsic value of the image" (10).

Ouro Preto, despite the lack of perspectives produced by wide avenues, maximizes its topographical singularities. Churches atop hills or with designs suggesting counterpoints to mountainous skylines often reveal exuberant vistas. As Baeta states, "difícil imaginar uma topografia menos adequada para a ereção racional de uma cidade, mas mais significativa no que se refere à organização dramática do espaço" (979). If in Rome the papal urban reforms of the seventeenth century sought to connect churches in pilgrimage routes, in Ouro Preto churches were visually connected through the interplay between architecture and topography. This which Baeta calls "caráter cenográfico, a comovente articulação barroca da Ouro Preto colonial" (981), allows us to think of the city's organization as coherently baroque, but also peculiar. Mumford describes the attitude of the baroque mind: "If the topography was irregular, the terrain must be evened out ..., traffic and geometry take precedence" (392). The unusually irregular topography of Minas Gerais led to a fascinating compromise: rather than indifference toward physical features, urban Ouro Preto fit the baroque mode to the dramatic contours of its landscape.

This geography and "baroque mode" are central to Cláudio Manuel da Costa's poetic imaginary. Affonso Ávila has called his epic Vila Rica part of the formation of a "consciência ótica" that creates and highlights "mármores cavados" or "edifícios soberbos" (Resíduos 94). Cláudio spent his early childhood near Vila Rica, in the region's other major urban center at the time, known as the Vila do Ribeirão do Carmo. He belonged to a first generation of Minas Gerais natives, or mineiros. His paternal grandparents came from humble Portuguese origins, while his maternal grandparents were from a well-situated lineage of São Paulo natives, or paulistas. Cláudio left Minas Gerais as a teenager some time in 1744 or 1745 to study at a Jesuit school in Rio de Janeiro. Since colonial Brazil did not have a university, like other well-off mineiros of his generation he attended the University of Coimbra in Portugal from 1749 to 1753. Between 1756 and 1757, Cláudio moved to Vila Rica, where he became a vereador in $1758 .{ }^{6}$ 
Cláudio Manuel da Costa went on to become one of Vila Rica's most brilliant and successful lawyers. Along with other magnates of Minas he would be "involved in a myriad of economic functions ... increasingly linked to the regional economy in a way that the great producers of colonial staples elsewhere in Portuguese America could never be" (Maxwell 91). Even among these men, or at least the twenty-three convicted for participation in what became known as the Inconfidência Mineira, Cláudio Manuel da Costa was the only one involved with all four major economic activities-mining, farming, finances and bureaucracy - while also holding a university degree (Furtado, Manto 26-7). In literary histories, Cláudio Manuel da Costa most frequently appears as the figure who introduced neoclassicism into what would eventually be deemed Brazilian literature, and as one of the most significant eighteenth-century poets in the Portuguese language. In the context of a colony without a printing press, his collection Obras was published in Coimbra, in $1768 .^{7}$

In the title page of that book, Cláudio Manuel da Costa is identified as an "Árcade Ultramarino." An Arcadian poet in a baroque city, he embodies tensions, changes, and apparent contradictions of the period. Cláudio Manuel da Costa stands out as both a representative and an exceptional figure of his milieu. In her fascinating biography, Laura de Mello e Souza emphasizes the idea of a "letrado dividido," torn apart by conflicting allegiances to Portugal and Minas Gerais. Earlier scholars had sought to explore other dimensions of Cláudio Manuel da Costa as a poet “entre mundos," or, rather, in a transitioning world. He has sometimes been read as a link between the baroque and neoclassicism, though not many studies have attempted to connect Cláudio's writings to his urban environment, or to his family life with a woman of African descent.

In the nearly 180 pages devoted to the poet in Capitulos de Literatura Colonial, Sérgio Buarque de Holanda characterizes Cláudio Manuel da Costa as essentially belonging to the baroque era. Buarque de Holanda finds relations between Cláudio's poetics and seventeenth-century treatises found in the latter's library, such as Baltasar Gracián's Agudeza y arte de ingenio and Emanuele Tesauro's Cannocchiale Aristotelico. Frequent use of hyperbata, parataxis, antitheses, the recurrence of extended metaphors, an overall desengano and the treatment of tropes 
like Polyphemus-with which the poet empathizes in poems like Écloga VIII, as predecessors such as Luis de Góngora had done-all reveal affinities with literary styles and themes that became associated with the baroque. ${ }^{8}$

Whereas Buarque de Holanda identifies these traits throughout Cláudio's poetic production, most critics tend to attribute baroque tendencies to his initial work. ${ }^{9}$ Melânia Silva de Aguiar, one of the principal experts on Cláudio’s poetry, refers to baroque influences in his circuitous language and the grandiloquent tone of his early encomiastic poetry (A Poesia 29-30). It might be tempting to ascribe a linear evolution to Cláudio Manuel da Costa's trajectory: from the young poet's baroque submission to the hierarchies of power in the 1750 s, to the Enlightenment intellectual's participation in a conspiracy against the Portuguese monarchy in the $1780 \mathrm{~s} .{ }^{10}$ Alas, later works-often in a style that was indeed less convoluted-also paid homage to government officials. Cláudio Manuel da Costa, however, can be understood as a master of dissimulation, a mark of both baroque and Arcadian modalities. Without attempting to impute a sort of spirit of dissent to his encomiastic poetry, might we not read it against the grain? As a type of correlating inverse of how baroque satire can reaffirm order and hierarchy—as João Adolfo Hansen demonstrates in A Sátira e o Engenho: Gregório de Matos e a Bahia do Século XVII-might we not interpret neoclassical encomiastic verses as potentially destabilizing? By showing what is unacceptable, satire provides guidelines to the body politic. By setting lofty standards that no actual administrator could meet, perhaps eighteenthcentury panegyric poetry sometimes served to undermine power.

Cláudio Manuel da Costa's writings and public life, at any rate, give ample indication that he was keenly aware of changing aesthetic and political currents-even if his participation in the Inconfidência ultimately led to a tragic death in prison. ${ }^{11}$ Eliana Scotti Muzzi suggests that "o lugar de onde fala o poeta ... é ... uma dupla encruzilhada entre o Novo e o Velho Mundo, não apenas na dimensão espacial, como também na temporal." To her, “ocupálo é elaborar um complexo sistema em que se busca articular a forte tradição seiscentista de cunho barroco, e seus últimos clarões, como o novo horizonte filosófico e político que se esboça na Europa e os primeiros balbucios de uma cultura emergente no áspero melting pot das Minas" (A Poesia 349). 
At once a man who created deep roots in Vila Rica and a cosmopolitan intellectual, Cláudio Manuel da Costa evokes these tensions between baroque legacies and the new horizons of the Enlightenment in his "Prólogo ao Leitor" to the Obras. Here, as part of an intricate exercise in the rhetoric of humility, Cláudio warns the reader that "te não faltará que censurar nas minhas Obras, principalmente nas Pastoris onde, preocupado da comua opinião, te não há de agradar a elegância de que são ornadas" (47). ${ }^{12}$ Ornamentation, often associated with baroque aesthetics by later scholars, distances Cláudio's "Pastoris" from Arcadian precepts like inutilia truncat (eliminate the useless). Aware of emerging neoclassical standards of good taste-reacting against Gongorism and baroque excesses-the poet reassures the reader: "encontrarás alguns lugares que te darão a conhecer como talvez não me é estranho o estilo simples" (47). He goes on to cite Theocritus, Virgil, and Sannazaro, along with four Portuguese poets of the 1500s and early 1600s: Francisco de Sá de Miranda, Diogo Bernardes, Francisco Rodrigues Lobo, and Luís de Camões. The prologue repeatedly calls attention to the poet's displacement, across the Atlantic from the Arcadias and Muses of his European literary models. This body of literature also emerges, in its own way, as an expression of the Minas melting pot.

Despite the competing styles associated with each, we need not understand the baroque and the Arcadian in Cláudio Manuel da Costa as necessarily in tension, or even as constituting a contradiction. We do need to consider, however, how Cláudio Manuel da Costa—as poet, family man, and public personacreated highly elaborate ways of bridging conflicting facets of his life. In a spirited passage of his Pindorama Revisitada, Nicolau Sevcenko writes that baroque art "suscita estados de harmonia sensorial que recompõem os fragmentos de um mundo sob tensões tão lancinantes, que o ameaçam desintegrar" (46). While in expressions usually considered baroque these states are reached through manifestations of the epiphanic, the ineffable, the impalpable-including a vibrant repertoire of religious processions and festivals-in Cláudio Manuel da Costa's poetry this sensorial harmony rests in the promises of pastoral serenity.

It is commonplace to consider pastoral literature as an urban genre. Fugere urbem (to flee the city), after all, presumes an urban setting as a starting place. This seems to have been the case for Theocritus, author of Idylls, and 
Syracuse; Virgil, author of Bucolics, and Rome; Sannazaro, author of Arcadia, and Naples. Cláudio Manuel da Costa, as we know, led an urban life in Vila Rica. His pastoral sonnets, epicedes, eclogues, epistles, romances, canzonette, and cantatas - which take up the vast majority of the 320 pages of Obras-fulfill the sine qua non of pastoral fictions: the presence of herdsmen, a demand that the etymology (pastor) evinces. ${ }^{13}$ The binary between city and nature, recurrent in the genre, can be found in some of Cláudio Manuel da Costa's verses. ${ }^{14}$ But even if his pastoral poems remain bound to relatively strict classical conventions and literary models, it certainly did not escape him that cities and nature meant different things in Europe and in Minas Gerais.

In his Estes penhascos: Cláudio Manuel da Costa e a paisagem das Minas (1753-1773), Sérgio Alcides posits that "um traço marcante e central da obra de Cláudio Manuel da Costa ... é a relação de conflito entre a persona poética do autor e a paisagem ao redor" (13). The author perspicaciously notes that the landscapes inhabited by his herdsmen are generally anything but the locus amoenus that we expect from bucolic poetry. In his Arcadia, uncharacteristically, "o pastor é triste, e a terra é triste" (14). Cláudio Manuel da Costa’s Arcadian name-Glauceste Satúrnio-itself might offer a clue about the melancholic predispositions of his poetic persona. Glauceste forms an assonant rhyme with Cláudio. Satúrnio recalls the Roman God-of agriculture, among other things-who presided over a Golden Age in Ovid's Metamorphoses and Virgil's Georgics and Aeneid. Ambivalent, Saturn also connoted destruction and dissolution: according to Bryan Turner, "the baroque culture dwelt upon the image of Saturn," in connection to its "profound sense of social change and decadence" (Buci-Glucksmann 23).

Cláudio Manuel da Costa sets some of his pastoral poems in the landscapes of the Old World, where his shepherds inhabit the Tejo and the Mondego of Portuguese lyrical tradition. Although he claims in the prologue of Obras that the greater part of its content was written while in Coimbra or shortly thereafter, the first sentence situates his voice as emanating "desde os sertões da Capitania das Minas Gerais" (47). Eclogue I, written at the occasion of the marriage of D. Maria, daughter of El-Rei José I, to D. Pedro III, refers to the "montes d'ouro" that "a América te envia" (129). Eclogues II and III, neither 
set in the poet's native country, refer to an "idade de ouro." Several authorsHesiod, Theocritus, Virgil, etc.-make reference to a Golden Age, often situated in an out-of-reach mythical past. ${ }^{15}$ Glauceste Satúrnio is engaging a trope of Arcadian poetry, but this is not merely the Golden Age of Saturn or of literary imaginaries. Cláudio Manuel da Costa knew that in Vila Rica, gold was never just a metaphor.

The "Fundamento Histórico" preceding Vila Rica, Cláudio's epic poem about the city's foundation, refers in great detail to the discovery and early exploration of gold in the seventeenth century. ${ }^{16}$ It is as if the poet anticipated Antônio Risério's insight that Vila Rica, or Ouro Preto, "sofreu a incontornável determinação da localização do ouro," and as such, "o ouro foi o grande e verdadeiro urbanista de Ouro Preto" (115). To someone of Cláudio’s generation and social standing, mentions of a Golden Age likely generated an irony that was difficult to avoid: the gold production of Minas Gerais experienced a steady decline throughout the second half of the eighteenth century. Between 1745 and 1785, it was cut in half (Arruda 386-88). It is unclear whether the proximity of an actual "idade de ouro" and a sense of impending decadence helped to shape Cláudio’s poetic sensibilities, but the extractive mining economy surely did alter the landscapes around him: "O ouro obrigou à ocupação do vale e das cumeadas" (Risério 115). Urban networks developed along routes connecting places where gold and diamond were found. ${ }^{17}$

In the prologue to Obras, Cláudio Manuel da Costa introduces a note of ambivalence regarding some of the effects of mining. In a reference to his native landscape, after he declares that "não são estas as venturosas praias de Arcádia," a description of local rivers reveals displeasure with the environmental impact of mining: "Turva, e feia, a corrente destes ribeiros, primeiro que arrebate as idéias de um Poeta, deixa ponderar a ambiciosa fadiga de mineirar a terra, que lhes tem pervertido as cores" (45). It is fitting that this is framed as an aesthetic matter: mining activities darken the waters, rendering them ugly. Beyond the baroque primacy of the visual in the passage's attention to color, it appears that baroque desengano and melancholia are not the only reasons for the nature of Minas Gerais standing more as a locus horribilis than a locus amoenus. Despite the extent to which pastoral conventions shaped Cláudio's 
poetry, the fiction of local nature as a respite from urban pressures was perhaps too far-fetched in a context where escaping the city led to contact with mining activities, or worse, with the threatening wilderness of "savages." 18

Simon Schama argues that Roman and Renaissance authors redesigned and domesticated the original Greek Arcadias, beastly landscapes where Pan copulated with goats and relationships between humans, divinities and animals were marked by continuities (526-38). Cláudio Manuel da Costa’s pastorals are by no means a return to this "original" wildness, but perhaps their representation of a disagreeable landscape also owes to the sense that outside of cities, civilization is at peril. There are no echoes here of a Jeffersonian "agrarian republic," which in North America "transformed what was originally a literary convention" - the pastoral_ "into a political theory," whereby the country rather than the city provides models of good citizenship (Bender 5). In Cláudio's Minas Gerais, nature was not presided over by mythic Pan, nor by virtuous farmers. It was still the realm of "bárbaros Gentios," an epithet that recurs in his verses. The epic Vila Rica is to no small degree a foundational narrative of wilderness subsumed by civilizing colonial force. In the very title, it is not a heroic figure, a people, or a nation that the poem attempts to commemorate, but rather the foundation of a city, as evidenced by the last stanza: "Enfim serás cantada, Vila Rica / Teu nome impresso nas memórias” (446). ${ }^{19}$

Urban Minas Gerais, like its natural landscape, also diverged from European counterparts in ways that must have been readily apparent to Cláudio Manuel da Costa. Gold was the driving force behind Ouro Preto's development, and in a slave-based economy, this had profound consequences for the city's demography. According to the 1776 census, the Comarca of Vila Rica, which also included the town of Mariana, had a mostly black population: 12,679 bran$\cos (16.1 \%), 16,791$ pardos (21.4\%) and 49,148 pretos (62.5\%), totaling 78,615 (Vasconcellos 35 ). The town was likely composed mostly of slaves, and had a significant gender imbalance: $6.1 \%$ of the Comarca was comprised of brancas; $11.2 \%$ of pardas; $19.3 \%$ of pretas (totaling $36.6 \%$ ). Like other white men of Minas, Cláudio Manuel da Costa had a relationship with a woman of African descent. ${ }^{20}$ His relationship with Francisca Arcângela de Souza, a freed woman, lasted from 1759 until his death in 1789. 
Although we cannot ascertain details of Cláudio's life with Francisca, we are left with enough to paint a picture of a man with some sort of family life, which included five children. Archival documents-many presented in this essay for the first time-suggest that Cláudio Manuel da Costa regarded his children and companion as legitimate heirs to his name, regardless of social norms dictating that marital relations be based on a "princípio de igualdade" (Villalta 383). The Autos de Devassa da Inconfidência Mineira, the documentation of the proceedings following the imprisonment of the so-called inconfidentes, provides the following regarding Cláudio's "situação familiar": "era solteiro e deixou duas filhas naturais," Francisca and Maria (III: 345). Unlike "spurious" children, "natural offspring" enjoyed special status, singled out as "favored heirs in ab intestato succession" (Lewin 44). Maria was said to be about eleven years old. Their mother, listed as Francisca Cardoso, appears as "solteira," without property, and residing in Vila Rica. The records state that their older daughter, also named Francisca, received from her father "a metade de uma roça" along with three or four slaves on the occasion of her wedding.

Cláudio's commitment to his family becomes apparent in his own statements, on July 2, 1789. ${ }^{21}$ During the interrogations, two days before his death, he laments the "injúria" that being imprisoned caused to his "inocente família e ... seus irmãos." Mention of his brothers could only have meant that by family he implied Francisca and their children. He reiterates that they are "em tudo inocentes e sustentados com honra" (Autos II: 123). In the footnotes to the second edition of the Autos, Tarquínio de Oliveira writes that Cláudio and Francisca had five children together. He lists their names and dates of birth, and claims that the surname Cardoso came from Francisca's slave master and was changed to Arcângela de Souza after she obtained freedom at the baptism of their second son (Feliciano, born in 1765). Such manumission practices did take place, but Tarquínio does not cite any sources. ${ }^{22}$

Feliciano's baptismal record, unpublished until now, confirms Francisca's status as a former slave: "Ao vinte e sete dias do mes de Abril do anno de mil setecentos e sessenta e cinco nesta Matriz baptizei, e pus os santos óleos à Feliciano inocente, nascido à 9 do corrente, filho natural de pai incógnito, e de Francisca Archangela, parda, forra, solteira, moradora da Praca desta Villa." ${ }^{23}$ 
To omit the father's name was a common practice for children born out of wedlock. Receiving the "santos óleos" and being deemed "inocente" constitute a sign of approval by the Church. It was also common for a "natural" child to inherit the father's surname. Feliciano became a painter, not an unusual occupation for a mulato. He provided services for the Tertiary Order of São Francisco, where his father had been appointed as an attorney in $1771 .{ }^{24}$

After Cláudio's death, Feliciano Manuel da Costa and his mother lived together, according to the 1804 census (Mathias 71). Francisca appears as sixty years old, which means she would have been about fifteen years younger than Cláudio. She is listed as head of the household, mother of five, and owner of two slaves, Ana and Josefa, the latter the same name as a slave mentioned in Cláudio's "autos de sequestro" (Autos VI: 103). An inventory, hitherto unexplored, indicates that Francisca was reasonably well off when she died on June 28, 1818, single and without leaving a will. Her daughters were determined to be legal heirs to her property. In the records of the proceedings tied to that effort, which lasted from 1822 to 1823 , we find that Francisca owned substantial jewelry, silverware, furniture, and three "moradas." 25

One of the ways in which baroque urbanity meets Arcadian poetry is in their consciousness of theatricality, encapsulated in the theatrum mundi trope. In the first, the city is a stage. In the second, urbane lawyers write themselves as shepherds that speak in metrified verse. The roles ascribed to slaves or blacks like Francisca were clearly delineated in a place like Vila Rica. How does Cláudio Manuel da Costa conciliate his ambitions as a public man with his family life? Laura de Mello e Souza speculates that "o amor por Francisca" might have led the poet to definitively abandon the pursuit of an ecclesiastical career (80). She contends, however, that "para todos os efeitos, Cláudio Manuel da Costa vivia só," their relationship "era sabida mas não publicada ostensivamente" (141). The circumstantial evidence, nonetheless, suggests that Francisca was more than a concubine, and that at least in private they had some type of family life. She was, at the very least, a companion of three decades and the mother of Cláudio's children.

Interest in Francisca has been remarkably tepid, in sharp contrast to the fascination exerted by the relationships of other inconfidentes: Alvarenga Peixoto’s Bárbara Heliodora and Tomás Gonzaga’s "Marília” (Maria Doroteia 
Joaquina de Seixas), both white women, sometimes have their stories depicted in keeping with European narratives of forbidden love. A comparable interracial relationship in the North American context, between Thomas Jefferson and Sally Hemings, has generated heated debates and extensive studies. It is perhaps not inappropriate to suggest that the relative indifference toward Cláudio Manuel da Costa's companion masks a Brazilian expectation of mulatas as figures of sexuality and seduction, but seldom of motherhood and stability. ${ }^{26}$ In Francisca, we might have a woman of African descent that defies literary and cultural stereotypes. Cláudio Manuel da Costa never wrote about her directly, and we do not know his opinions regarding race and slavery, but we can turn to his writings for clues.

We can infer that Cláudio was present at meetings in which the granting of liberty to slaves was discussed (Autos IV: 147, 398). We also know that at the time of his imprisonment he owned at least twenty-nine slaves (Autos VI: 10106). In an unpublished manuscript titled Notícias da Capitania de Minas Gerais, he mentions the enslavement of Indians prior to the African trade: "Paulistas Conquistadores ... se ocuparão ... na conquista do Gentio, capturando-os, para com elles substituirem a falta de escravos, que depois entrarão em grande número das Costas d'Africa" (3). ${ }^{27}$ The text later refers to "pretos," "pretos libertos," "forros," "Africanos" and "pardos" as donors to the bishopric, members of religious brotherhoods and companhias de ordenanças, and taxpayers, even mentioning a "boa civilidade" in the relations between troops of different colors (48). On occasion, Cláudio demonstrates admiration and sympathy toward the "belissimamente paramentadas" churches of black brotherhoods. Writing on the Arraial do Tijuco (Diamantina), Cláudio praises a church, "[cultivada] pelos pretos da Costa d'Affrica, em q/ festejão com muita grandeza a N. Sra. do Rozario." In a footnote to Vila Rica, he mentions "o grande trabalho e fadiga dos negros, Índios e bastardos," who he compares to Janissaries (1085).

Cláudio Manuel da Costa and his peers were attuned to Enlightenment debates around political philosophy, and later, developments in the "Américas Inglesas." 28 They seem to have remained, however, at the margins of emergent eighteenth-century racial theories, whereby color differences became increasingly represented as "fixed in nature" rather than caused by it. ${ }^{29}$ Skin color 
was a very important signifier in eighteenth-century Vila Rica, and prejudices abounded. Membership in the Order of Christ, which Cláudio sought for a decade and gained in 1771, excluded those with "raça infecta"-Muslims, Jews, Blacks, Indians-among their descendants (Souza 110). In his writings, race and skin color had political and aesthetic dimensions, but they were not yet the provenance of scientific thought. Echoing most natural philosophers of the sixteenth and seventeenth centuries, his poetry represents skin color as a factor of environment and climate. In Vila Rica, for example, we read: "todo o corpo adusto / Mostra que o sol sobre a nudez queimara, / E que a ingênita cor de branca e clara / Tornou um pouco escura" (380).

Christian belief in humanity's descent from Adam and Even meant that monogenist explanations prevailed, in spite of notions of "tainted" blood. As George Fredrickson explains, "the theory of polygenesis would thrive only when the power of biblical literalism declined" (52). While eighteenth-century intellectuals invent the modern concept of race "as basic human types classified by physical characteristics (primarily skin color)” (52), Cláudio's views of "race" belong to another, earlier world. Rather than scientific, they are unstable, fluid, and more concerned with surface appearance. In other words, we might say, baroque. How then does this "baroque" aesthetic of race, skin color prejudices, and life with Francisca intersect with his poetic production? Is there room in his Arcadian poetry for references to a partner of African descent?

Edward Lopes argues that in Écloga XV, the poet's "real" love-the Francisca of his "physical reality"-is metamorphosed into the imaginary reality (92). Her transfiguration would be signaled by Beliza as a simulacrum of Francisca, and Corebo as a simulacrum of Cláudio. In that poem, the shepherds Corebo and Beliza are lovers; and the other couple, Amarilis and Palemo, according to Lopes, represent Marília and Tomás Gonzaga. Cryptic-onomastic games such as these are typical of Arcadian poetry, and Lopes postulates that almost everything in Cláudio's poems is simulation and imitation, in accordance to conventions of the period (113). As the poet assumes the personae of shepherds, simulating various settings for the narration of often unfulfilled loves, themes like the pursuit of a beloved cannot be understood without the imitation of models (Virgil, Petrarch, Camões, etc.). But here and there, as 
Lopes suggests, Cláudio seems to allow himself to play with inherited conventions, incorporating local geography and inserting characters that contemporary local readers might easily identify.

That process occurs more explicitly in the satirical verses of the "Cartas Chilenas." Ostensibly set in Chile, the letters take aim at the governor of Minas Gerais, Luís da Cunha Meneses, Fanfarrão Minésio in the poem. Written by a Critilo and addressed to a Doroteu, the texts likely circulated in manuscript form during the 1780s. Most scholars have accepted the thesis that Tomás Gonzaga wrote as Critilo and Cláudio Manuel da Costa as Doroteu. Gonzaga, a fellow Arcadian poet and close friend of Cláudio, also became a central figure of the Inconfidência. Lapa interprets verses where Gonzaga’s Critilo makes an oath as a mocking but good-humored reference to Francisca: "uma mulher zelosa me atormente / e tenha um bando de gatunos filhos" (48). Gonzaga, fifteen years younger than Cláudio, did not have children.

Other verses toward the end of Cartas also seem to allude to Francisca. This time, Critilo asks that Cláudio's Doroteu swear by his beloved wife that he will not doubt the stories told: "E tu, meu Doroteu, antes que leias / O que vou a contar-te, jurar deves / Pelos olhos da tua amada esposa, / Por seu louro cabelo, e pelo dia / Em que viste, na sua alegre boca, / O primeiro sorriso" (231). Adelto Gonçalves writes that Gonzaga, who lived near Cláudio, often saw Francisca leaving for religious processions with her hair decorated with gold powder. Indeed, Cláudio describes the practice in other poems. ${ }^{30}$ To Gonçalves, the verses constitute an irony that might sound offensive to modern readers but would have been met by the reserved Cláudio with a silent smile (108). Gonzaga's disparaging references to blacks and mulatos, incidentally, lead Lapa to conclude that he was a man of greater prejudices than Cláudio (29-34).

It is possible that Gonzaga's ironic reference to Francisca's "blond hair" dialogues with Cláudio Manuel da Costa’s earlier poetry. In Vila Rica, we have "as porções de ouro / Com que [uma Ninfa] esmalta o cabelo e o torna louro" (386), and later "[Eulina] Toma uma areia de ouro, e já com ela / Pulveriza os cabelos" (416). Even earlier, in "Fábula de Ribeirão do Carmo"-published in Obras-Cláudio might already introduce the "blond" Francisca evoked by Gonzaga, as Gonçalves also points out. Significantly, like the epic, the Fábula 
is set in Minas Gerais, among local streams, nymphs, and a beloved named Eulina. In it, Cláudio Manuel da Costa transfigures the literary trope of the blond hair, projecting his "amada esposa" onto a tradition that did not contemplate women of African descent. Representations of Eulina condense Apollinean associations between gold and sun, Petrarchan and Camonian abstraction of the unattainable beloved, and the native of the Minas "melting pot" who decorated her hair with gold powder:

\author{
Mais formosa de Eulina \\ Respirava a beleza; \\ De ouro a madeixa rica e peregrina \\ Dos corações faz presa; \\ A cândida porção da neve bela \\ Entre as rosadas faces se congela (122).
}

The Eulina of the poem, called a "beleza nativa" in an earlier stanza, was fifteen (“Três lustros ...”), Francisca’s age when Cláudio met her. In this context, the adjective "peregrina" implies being of rare beauty. Per Rafael Bluteau’s eighteenthcentury dictionary, it also meant foreign, strange or singular (186). Francisca's hair might have seemed so to a man who had returned to miscegenated Vila Rica from Coimbra. It was certainly so within a Western canon full of flowing blond hair. We can imagine the "porção" of snow-like complexion in a woman of presumably partial European descent, and elsewhere the poem suggests an allegorical reading of color: several stanzas later the lyric voice-the Ribeirão itself-declares that "Do sangue, que exalei, ó bela Eulina, / A cor inda conservo peregrina" (124).

The adjective "peregrina" reoccurs in association to a beloved's hair in another poem from Obras. But the "formosa" in this sonnet is Daliana, less abstract than this other Eulina, and between them the expression "letrado dividido" gains new connotations:

Formosa é Daliana; o seu cabelo,

A testa, a sobrancelha é peregrina;

Mas nada tem, que ver coa bela Eulina, 
Que é todo o meu amor, o meu desvê-lo:

Parece escura a neve em paralelo

Da sua branca face; onde a bonina

As cores misturou na cor mais fina,

Que faz sobressair seu rosto belo (55-6).

Cláudio Manuel da Costa's relocation of the snow and "bonina"-a recurrent flower in Portuguese poetry-to the tropics parallels his own move from Europe to Minas Gerais. Inside the poem, both images invoke the purity of Eulina, but their artificiality befits the drama of an Arcadian poet in a baroque cityamong few who had ever been anywhere near snow. Associations between whiteness and purity aside, Eulina's personification of the poet's love could be read with a certain dose of irony by those aware of Francisca. The sonnet sets up a conflictive relation between the physical and "peregrina" Daliana and the more abstract, literary Eulina. Daliana might evoke Francisca: "peregrina" is again associated to physical features, and her name may be read as a simulacrum of curly hair. ${ }^{31}$ Whether Eulina in this sonnet also represents Francisca can only remain ambiguous, as much as the image of a mixture of colors making her white face "sobressair" suggests—avant la lettre-the metaphor of miscegenation. It more plausibly draws upon literary tropes where poets render as absurd anything belonging to the natural world-like skin color-in order to express the intensity of a feeling.

Cláudio Manuel da Costa is a difficult poet to pin down. Like most writers of the pastoral, he exhibits an awareness of the production of nature through artifice. A dramatist and likely translator of operas by Metastasio, a man of political aspirations, Cláudio was no stranger to performance. Sérgio Buarque de Holanda proposes that his "formas arcádicas e modernas" represent "apenas um disfarce externo" (281), whereas for Helio Lopes the poet also knows how to "ocultar-se ... atrás do formalismo barroco, sinuoso e complexo" (Letras 100). Luciano Figueiredo implies that participation in the "inconfidência" might have constituted a "grande licença poética" (A Poesia xxxix). What then was behind the concern with appearance? What then was behind the masks? Cláudio's expression of sorrow with respect to his family during interrogation procedures, when he otherwise did little to protect his peers, seems to offer 
more clues than previously thought. Wearing a mask, "the essence of civility" as Richard Sennett puts it (264), can serve as a shield—against social pressures, harsh landscapes, a sense of estrangement. In this, Cláudio Manuel da Costa had remarkable skill, along with enough versatility to appear both baroque and Arcadian: different roles, different masks.

\section{Notes}

1 On the independence movement that became know as the "Inconfidência," see Maxwell. For a summary of its historiography, see Figueiredo (A Poesia xix-1). Minas Gerais became a captaincy distinct from São Paulo in 1720. The following year, Vila Rica was made its capital, and remained so until 1897. Vila Rica de Albuquerque was created in 1711 and named Vila Rica de Nossa Senhora do Pilar de Ouro Preto in 1712, changing its status from town to city the year after Brazil's independence (1822), when it was renamed Imperial Cidade de Ouro Preto. The nomenclatures "vila" and "cidade" were not necessarily tied to size and density. On Vila Rica, see Lima Júnior (Vila Rica) and Vasconcellos.

2 See Risério (76-100) and Lara (33-5).

3 Affonso Ávila calls the noted sculptor and architect, né Antônio Francisco Lisboa to a Portuguese man and his African slave, "dual, contraditório, dilacerado" (Risério 113).

4 See, for example, Mello or Ávila (Barroco).

5 This characteristic recurs in the literature on the baroque. Ávila, for example, traces the idea of a "modo de ver barroco" to Heinrich Wölfflin, Alois Riegl, and Leo Spitzer (Resíduos 85).

6 For details concerning the poet's biography, see Souza. For a more detailed study of the mineiros and the University of Coimbra, see Boschi.

7 The title page misspells it as Orbas. The collection, although published in Coimbra, at the "Officina de Luiz Secco Ferreira," marks the introduction of Arcadian poetry to Brazil. On "nativist" manifestations in the Arcadian poetry of the mineiros, see Candido. On Cláudio's attempts to create an Árcadia Ultramarina in Minas Gerais, see Souza (150-51).

8 For a detailed and insightful analysis of Sérgio Buarque's writings on Cláudio-and relations between the poet and discourses around baroque literature-see Gomes Junior (130-35).

9 See, for instance, Hélio Lopes (Letras 85) and Edward Lopes (65-79).

10 Cláudio seems to have formed the ideological backbone of the conspiracy along with fellow poet Tomás Gonzaga and the cleric Luís Vieira: to Maxwell, "their task was to formulate the laws and constitution of the new state and provide the ideological justification for the break with Portugal" (125).

11 Cláudio died while in prison. While suicide was given as the official explanation, several historians believe in the possibility of murder (Maxwell 138-41).

12 Unless otherwise noted, Cláudio Manuel da Costa's works will be cited from A Poesia dos inconfidentes.

13 Countless literary critics have written about pastoral genres or modes. On defining the pastoral, see Alpers (8-43).

14 Cities are represented as places of betrayal, intrigue and affliction in, among others, sonnets V (55), XIV (57), and Eclogue XIX (240). 
15 On the trope of the Golden Age across different time periods, see Minois.

16 Concluded in 1773, Vila Rica was published posthumously in Ouro Preto's Tipografia do Universal, 1839.

17 For a study of the process, see Fonseca.

18 As Hal Langfur writes, "for the barons of the Minas gold boom gathered in Vila Rica and other major towns," the sertão of Indians and colonists lacking in culture and civilization "encircled the settled mining district" (293-94). Souza speculates that "índios bravos" likely populated Cláudio's childhood nightmares (33), and writes about a nearly three-month-long "viagem dilatada e aspérrima" that he undertook through the Minas sertões (118-28). Alcides also writes about the trip, and its potential effects on the poet's sensibilities (239-40).

19 Like other epics-Lucano's Pharsalia, for instance-Vila Rica deals with a recent conflict, the War of the Emboabas in Cláudio's case. There are no intromissions of pagan divinities in its ten Cantos of decasyllables, in paired rhymes like Voltaire's Henriade. For a study of the poem, see Lopes (Introdução).

20 Luís Monteiro, Governor of Rio de Janeiro in 1730, claimed that "não há mineiro que possa viver sem nenhuma negra mina" (Freyre 516). See Furtado's landmark study, Chica da Silva.

21 The records of Cláudio's interrogation were not published in the first edition of the Autos (1938), but later surfaced in Lisbon (Maxwell 161).

22 Prior to the second edition of the Autos, Lima Júnior mentions Feliciano as their "filho natural," also without attribution (Cláudio Manoel da Costa 12).

23 Igreja Matriz de Nossa Senhora da Conceição e capelas de Freguesia, Vila Rica, cod. 458, vol. 071 [1740-1773], p. 352. Casa dos Contos, Ouro Preto, Minas Gerais.

24 The painter "Feliciano M.el da Costa" appears in the order's published records as receiving payments in gold in 1794 and 1800 (Trindade 411-12). This publication, from 1951, lists him in the footnotes as "Filho natural do Dr. Cláudio Manuel da Costa" (482).

25 Inventários [de Francisca Archangelo de Souza], vol. 1673, 26/06/1823. Casa do Pilar, Ouro Preto, Minas Gerais. I am grateful to Prof. Luis Carlos Villalta, who helped me to locate this document.

26 Chica da Silva’s representations in popular culture, prior to Júnia Furtado's research, illustrate the point. In a study of color prejudices in Brazilian literature, Queiroz Júnior points out that none of the mulatas in the novels he examined were mothers. I am indebted to Elio Gaspari for suggesting this source and line of thought. Cláudio Manuel da Costa’s biography in the Academia Brasileira de Letras' site lists him as "solteiro" and father of "filhos naturais," with no mention of Francisca.

27 Notícias da Capitania de Minas Gerais por Cláudio Manuel da Costa. Mss., DL 824.14. IHGB, Rio de Janeiro.

28 See Maxwell, Carvalho, Huffman, and Rocha, O livro de Tiradentes.

29 The quote is from Thomas Jefferson's theorizations of racial difference in his 1787 Notes on the State of Virginia (176). Scholars have been increasingly locating some of the origins of scientific racism in Enlightenment authors (see Eze and Jackson).

30 Corroborating Francisca’s habit of "blonding" her hair, in the records of Cláudio's confiscated properties we find sixty-one and a half oitavas of gold powder delivered to someone assisting the prisoner, Adão Cardoso. This surname leads Tarquínio to speculate that Adão was related to Francisca, also a Cardoso before manumission (Autos II: 125).

31 I am grateful to Prof. Joaquim-Francisco Coelho for pointing out the possibility of this allusion ("da liana”). 


\section{Works Cited}

\section{Primary Sources}

Igreja Matriz de Nossa Senhora da Conceição e capelas de Freguesia, Vila Rica, cod. 458, vol. 071 [1740-1773]. Casa dos Contos, Ouro Preto, Minas Gerais.

Inventários. Vol. 1673, 26/06/1823. Casa do Pilar, Ouro Preto, Minas Gerais.

Notícias da Capitania de Minas Gerais por Cláudio Manuel da Costa. Mss., DL 824.14. Instituto Histórico e Geográfico Brasileiro, Rio de Janeiro.

\section{Secondary Sources}

A Poesia dos inconfidentes: poesia completa de Cláudio Manuel da Costa, Tomás Antônio Gonzaga, e Alvarenga Peixoto. Ed. Domício Proença Filho. Rio de Janeiro: Nova Aguilar, 1996. Print.

Autos de Devassa da Inconfidência Mineira. 9 vols. Brasília/Belo Horizonte: Câmara dos Deputados/Governo do Estado de Minas Gerais, 1976-1983. Print.

Alcides, Sérgio. Estes penhascos: Cláudio Manuel da Costa e a paisagem das Minas (1753-1773). São Paulo: Hucitec, 2003. Print.

Alpers, Paul. What is Pastoral? Chicago: U of Chicago P, 1996. Print.

Argan, Giulio Carlo. The Baroque Age. New York: Rizzoli, 1989. Print.

Arruda, José Jobson de Andrade. "Colonies as Mercantile Investments: The Luso-Brazilian Empire, 1500-1808." The Political Economy of Merchant Empires. Ed. James Tracy. Cambridge: Cambridge UP, 1997. 360-420. Print.

Ávila, Affonso. Iniciação ao barroco mineiro. São Paulo: Nobel, 1984. Print.

- Barroco mineiro, glossário de arquitetura e ornamentação. Rio de Janeiro: Companhia Editora Nacional, 1980. Print.

— Resíduos seiscentistas em Minas: textos do século do ouro e as projeções do mundo barroco. Belo Horizonte: Centro de Estudos Mineiros, 1967. Print.

Baeta, Rodrigo Espinha. "Ouro Preto: Cidade Barroca." Cadernos PPG-AU/UFBA 1.1 (2002): 971-83. Print.

Bender, Thomas. Toward an Urban Vision: Ideas and Institutions in Nineteenth-Century America. Baltimore: Johns Hopkins UP, 1982. Print.

Bluteau, Rafael. Diccionario da lingua portugueza. Ed. António Morais de Silva. Lisbon: Ferreira, 1789. Print.

Boschi, Caio César. "A Universidade de Coimbra e a formação intelectual das elites mineiras coloniais." Revista Estudos Históricos 7 (1991): 100-11. Print.

Buci-Glucksmann, Christine. Baroque Reason: The Aesthetics of Modernity. Trans. Patrick Camiller. Thousand Oaks, CA: Sage, 1994. Print.

Candido, Antonio. Formação da literatura brasileira. Vol. 1. São Paulo: Martins, 1959. Print.

Eze, Emmanuel Chukwudi, ed. Race and the Enlightenment: A Reader. Malden, MA: WileyBlackwell, 1997. Print.

Fonseca, Cláudia Damasceno. Des terres aux villes de lor: pouvoirs et territoires urbains au Minas Gerais (Brésil, XVIIIe siècle). Paris: Gulbenkian, 2003. Print. 
Fredrickson, George M. Racism: A Short History. Princeton, NJ: Princeton UP, 2002. Print.

Furtado, João Pinto. O Manto de Penélope: história, mito e memória da Inconfidência Mineira de 1788-9. São Paulo: Companhia das Letras, 2002. Print.

Furtado, Júnia Ferreira. Chica da Silva: A Brazilian Slave of the Eighteenth Century. Cambridge: Cambridge UP, 2009. Print.

Gomes Júnior, Guilherme Simões. Palavra peregrina: o Barroco e o pensamento sobre artes e letras no Brasil. São Paulo: Edusp/FAPESP, 1998. Print.

Gonçalves, Adelto. Gonzaga, um poeta do iluminismo: biografia. Rio de Janeiro: Nova Fronteira, 1999. Print.

Hansen, João Adolfo. A sátira e o engenho: Gregório de Matos e a Bahia do século XVII. São Paulo: Secretaria de Estado da Cultura/Companhia das Letras, 1989. Print.

Holanda, Sérgio Buarque de. Raízes do Brasil. São Paulo: Companhia das Letras, 2006. Print.

—. Capítulos de literatura colonial. Ed. Antonio Candido. São Paulo: Brasiliense, 1991. Print.

Jackson, John P., and Nadine Weidman. Race, Racism, and Science: Social Impact and Interaction. New Brunswick, NJ: Rutgers UP, 2006. Print.

Jefferson, Thomas. Notes on the State of Virginia. Ed. David Waldstreicher. New York: Palgrave, 2002. Print.

Kaup, Monika, and Lois Parkinson Zamora, eds. Baroque New Worlds: Representation, Transculturation, Counterconquest. Durham, NC: Duke UP, 2010. Print.

Langfur, Hal. The Forbidden Lands: Colonial Identity, Frontier Violence, and the Persistence of Brazil's Eastern Indians, 1750-1830. Stanford: Stanford UP, 2006. Print.

Lapa, Manuel Rodrigues. "Cartas Chilenas": um problema histórico e filológico. Rio de Janeiro: Ministério da Educação e Cultura, Instituto Nacional do Livro, 1958. Print.

Lara, Silvia Hunold. Fragmentos setecentistas: escravidão, cultura e poder na América portuguesa. São Paulo: Companhia das Letras, 2007. Print.

Lewin, Linda. Surprise Heirs. Stanford: Stanford UP, 2003. Print.

Lima Júnior, Augusto de. Cláudio Manoel da Costa e seu poema: Vila Rica. Belo Horizonte: Nova, 1969. Print.

—. Vila Rica do Ouro Preto: síntese histórica e descritiva. Ed. Aristóteles Drummond. Rio de Janeiro: EGL, 1996. Print.

Lopes, Edward. Metamorfoses: a poesia de Cláudio Manuel da Costa. São Paulo: UNESP, 1997. Print.

Lopes, Hélio. Introdução ao poema Vila Rica. Muriaé: Edição do Autor, 1985.

—. Letras de Minas e outros ensaios. Ed. Alfredo Bosi. São Paulo: Edusp, 1997. Print.

Mathias, Herculano Gomes. Um recenseamento na Capitania de Minas Gerais, Vila Rica 1804. Rio de Janeiro: Arquivo Nacional, 1969. Print.

Maxwell, Kenneth. Conflicts and Conspiracies: Brazil and Portugal 1750-1808. London: Routledge, 2004. Print.

—., Bruno Carvalho, John Huffman, and Gabriel Rocha, eds. O Livro de Tiradentes: Transmissão Atlântica de Ideias Políticas no Século XVIII. São Paulo: Penguin/Companhia das Letras, 2013. Print.

Mello, Suzy de. Barroco mineiro. São Paulo: Brasiliense, 1985. Print.

Minois, Georges. Lâge d'or: histoire de la poursuite du bonheur. Paris: Fayard, 2009. Print. 
Mumford, Lewis. The City in History: Its Origins, Its Transformations, and Its Prospects. New York: Houghton Mifflin Harcourt, 1961. Print.

Queiroz Júnior, Teófilo de. Preconceito de cor e a mulata na literatura brasileira. São Paulo: Ática, 1975. Print.

Rama, Ángel. The Lettered City. Trans. John Charles Chasteen. Durham: Duke UP, 1996. Print.

Rinne, Katherine Wentworth. The Waters of Rome: Aqueducts, Fountains, and the Birth of the Baroque City. New Haven, CT: Yale UP, 2010. Print.

Risério, Antonio. A Cidade no Brasil. São Paulo: Editora 34, 2012. Print.

Schama, Simon. Landscape and Memory. New York: Knopf, 1995. Print.

Sennett, Richard. The Fall of Public Man. New York: Knopf, 1977. Print.

Sevcenko, Nicolau. Pindorama revisitada: cultura e sociedade em tempos de virada. São Paulo: Fundação Peirópolos, 2000. Print.

Souza, Laura de Mello e. Cláudio Manuel da Costa. São Paulo: Companhia das Letras, 2011. Print.

Trindade, Raimundo. São Francisco de Assis de Ouro Prêto; crônica narrada pelos documentos da ordem. Rio de Janeiro: Diretoria do Patrimônio Histórico e Artístico Nacional, 1951. Print.

Vasconcellos, Sylvio de. Vila Rica: formação e desenvolvimento, residências. São Paulo: Perspectiva, 1977. Print.

Villalta, Luiz Carlos. "O diabo na livraria dos inconfidentes." Tempo e História. Ed. Adauto Novaes. São Paulo: Companhia das Letras, 1992. 367-95. Print.

Bruno Carvalho is Assistant Professor in the Department of Spanish and Portuguese Languages and Cultures at Princeton University. He is the author of Porous City: A Cultural History of Rio de Janeiro, from the 1810s onward (2013), and co-editor of $O$ Livro de Tiradentes: Transmissão atlântica de ideias políticas no século XVIII (2013). $\mathrm{He}$ is currently working on a book about the Luso-Brazilian eighteenth century, tentatively titled Partial Enlightenments. 